\title{
History of EISCAT - Part 3: The early history of EISCAT in Norway
}

\author{
O. Holt \\ Professor emeritus of the University of Troms $\varnothing$, Norway \\ Correspondence to: O. Holt (olavhol2@online.no)
}

Received: 25 January 2012 - Accepted: 16 February 2012 - Published: 6 March 2012

\begin{abstract}
The paper describes the Norwegian participation in the EISCAT project during the first years of planning the facility. This includes obtaining the support of the relevant research groups as well as the possible funding agencies. Attention is also given to strengthening the competence and capacity of the potential user groups, along with taking part in the cooperation with the participating groups in other countries.
\end{abstract}

\section{Introduction}

In the following I shall present some personal memories from the earliest phase of planning EISCAT, an incoherent scatter radar in the auroral zone. This period is probably not so well covered in EISCAT's own archives. My emphasis will naturally be on the activities in Norway, and the Norwegian participation in the international cooperation. I have had the privilege and pleasure of reading similar presentations from Finland and Sweden, by Juhani Oksman and Bengt Hultqvist, respectively. I have not kept such accurate personal files as Oksman has, and which is extensively referred to in his presentation. Reports and notes from meetings that I refer to, are most likely to be found in the files of the University of Troms $\varnothing$.

\section{Background}

My first knowledge of incoherent scattering as a method of studying the ionosphere came from reading Gordon's paper in Proc. IRE (Gordon, 1958) and Bowles' experimental verification published in Phys. Rev. Letters a few months later (Bowles, 1958). I had just become a member of the ionospheric physics group at the Norwegian Defense Research Establishment (NDRE), and was working on my master thesis. I was sharing an office with Tor Hagfors; otherwise I would probably not have understood the importance of these two papers. Tor was enthusiastic, but he also made it clear that such experiments were far too expensive to think that we could hope to do anything like that in Norway. He may have decided already to go to the US, but he stayed on to finish his thesis for the degree of Doctor of Philosophy at the University of Oslo. This was done within an NDRE project on VHF scattering in the lower ionosphere. After receiving the degree, Tor was given a fellowship to go to the US, and he went to Stanford University, to work in a group headed by Von Eshleman. Most of his time during the following two years was spent on theoretical studies of plasma physics and incoherent scattering. Returning to NDRE, Tor lectured us in these fields with enthusiasm and skill. At a NATO advanced study institute at Skeikampen in 1961 (where Bengt Hultqvist was also present) Tor presented a paper on "Incoherent scattering of radio waves as a method of studying the Ionosphere" (Hagfors, 1962).

In 1966 NDRE wanted me to go to the Auroral Observatory in Troms $\varnothing$ for a year or possibly more, to study the influence of aurora on radio communications, and learn more about auroral physics At the Observatory, the director, Einar Tønsberg, had recently suffered a stroke, and was not able to continue in his job. Professor Anders Omholt from the University of Oslo, had been appointed acting director, and moved to Troms $\varnothing$. As part of a plan to strengthen the Observatory and expand the staff, Omholt had brought with him two young scientists from Oslo. I was happy to be able to join the group, and arrived in Troms $\varnothing$ in September 1966.

In 1968 the staff had grown to eight physicists, four electronics engineers and three secretaries who also served as data reduction assistants and librarians. That summer Anders Omholt decided to return to Oslo, and I was asked to take over as acting director. For me the plan had also been 
to return to NDRE at Kjeller that year, but they generously agreed to extend my stay in Troms $\varnothing$ for one year. Earlier that year, the parliament (Stortinget) had decided to establish a university in Troms $\emptyset$. I was appointed member of an Interim board. The University of Troms $\varnothing$ was chartered in 1969. In June 1969 I was appointed professor of physics at the new university and director of the Observatory. It was with mixed feelings I sent a letter of resignation to NDRE, who had treated me so well, but I also felt that I was given a unique opportunity. Space and upper atmosphere research would be the core activity in a physics department at the new university. We could start looking for larger projects.

\section{Beginning cooperation across the borders}

Before he left Troms $\varnothing$, or perhaps shortly after, Anders Omholt told me that I ought to discuss with Bengt Hultqvist, the director of Kiruna Geophysical Observatory, a possible Scandinavian cooperation on incoherent scatter radar observations. I do not know if Omholt had ever talked to Bengt about this, or if he said so because I had expressed my disappointment that there would never be funds for such expensive activities in Norway. Neither do I remember when and where I first talked to Bengt about this, but we met on several meetings and symposia during the following year, and it must have been on one of those occasions. At that time a very good cooperation had been established between groups in Denmark, Sweden and Norway on instrumented rocket experiments in the ionosphere. My first thought was that this might be extended to include incoherent scatter observations. I soon realized that this was not such a good idea. Bengt had thought about the possibilities in much more detail than I had. He suggested that we should seek a partner in Finland, and look at the possibilities for a tristatic radar. That would mean an innovation compared with existing facilities, and it might help to obtain funding in the different countries if there would be substantial installations in each country. We agreed to write a PM to present a possible project to a conference on "Future ionospheric research in Europe", to be held in Lindau in June 1969. We worked on a common proposal by mail and telephone. Bengt and I were both present at the meeting in Lindau, and Bengt presented our plans, which were received with interest. However, at the same meeting, French scientists presented plans for an incoherent scatter radar to be placed on a ship to be operated in the northern auroral zone, and later be moved to the French research station at Kerguelen in Antarctica. There were voices from participants at the meeting that the Scandinavian and French groups should look into the possibilities of forming a joint project, but as far as I remember, no effort was made during the meeting to do so. We went home, determined to continue the planning as we had started, with the purpose of seeking support at the URSI General Assembly to be held in Ottawa two months later. I planned to go to Ottawa, but for some reason that
I do not remember, I had to cancel that. Bengt Hultqvist was there, and presented our plans, proposing that the General Assembly should adopt a resolution supporting the plan. This was indeed done, but the Assembly also supported the French project mentioned above, so we did not feel that we had made much progress (Hultqvist, 2011).

Professor Martti Tiuri, from the Helsinki University of Technology, had been present at the Lindau meeting, and he encouraged Professor Oksman at the University of Oulu (established in 1959), to consider a possible Finnish participation. Oksman invited representatives from Troms $\varnothing$ and Kiruna to a meeting in Oulu at the end of November 1969 (Oksman, 2011). I went to Oulu together with Arne Haug from the Auroral Observatory, Hultqvist came from Kiruna, and Oksman was joined by Tiuri, Kataja and Koivumaa from Finland. Bengt had in advance prepared a draft for a proposal (or agreement), which was indeed very helpful (Hultqvist, 2011). After a day and a half we agreed on a proposal. The intention was to plan for a modest facility, with a cost estimate of five million Canadian dollars. In hindsight, I must admit that the cost estimate was more like a "guesstimate". The intention was to submit this to the research councils and/or other relevant funding sources in the different countries.

Returning to Troms $\varnothing$ after the Oulu meeting, I felt responsible for promoting the plans within Norway. Applying for funds was an obvious task, and I wanted to discuss the project with the funding agencies at first opportunity, but equally important at that stage was to get accept for carrying on with the plans from the Norwegian physics community, and in particular from the groups working in ionospheric physics. Also, I would have to obtain support from the interim board of the University of Troms $\varnothing$. The University was expected to be willing to give high priority to this project, to the extent that a Physics department at the University should concentrate on auroral and ionospheric physics as the main research activity, probably for decades to come. Recruitment of staff for a physics department would have to be in accord with that.

Rather than reviewing the events chronologically, I shall describe as well as I remember, how we met with the different challenges. I wish I had made better notes from the many meetings and talks as they took place.

\section{The possible funding sources}

At an early stage I presented the plans to the Interim Board of the University of Troms $\varnothing$, where I was a member. Most of the members of the board were quite enthusiastic at the possibility of having a large international project tied to the university, but there were also some reluctance. At least one member feared that this was "a defense research project in disguise" (!), others were more concerned about the possible financial consequences. That was only natural. Money was certainly not in abundance, considering the many challenges 
at a new university. I made it clear that in my opinion we could forget about further Norwegian participation in the project if we did not get the full support of the university board. I may be wrong, but I think we actually voted on this, and the support was given, but it was also made clear that the University of Troms $\varnothing$ could not be solely responsible for the costs from the Norwegian side, and that this ought to be discussed with the research councils and with the Ministry of education.

At that time there were two research councils in Norway - the Royal Norwegian Research Council for Science and Technology (NTNF) and the Norwegian Research Council for Science and Humanities (NAVF). NTNF had supported the rocket research program mentioned above, through its division of space activities, but approaching them on the incoherent scatter program, I was met with the argument that they would limit themselves to instrumented rockets and/or satellites or the reception of signals from such. Therefore I turned to NAVF, and asked for a meeting with its director, Adolf Sandboe. NAVF was the main source of external grants to university groups, but trying to encourage research over a very wide spectrum, most grants were rather small, and none so far of the size that I was looking for. Sandboe, himself a physicist who had turned to administration, received me with interest and sympathy. I think that he was intrigued by the possibility that NAVF could be supporting a really big project, like NTNF had done on more than one occasion. On the surface, the two research councils should be complementary, but there was also some rivalry between them! I wondered if that might be to our advantage. Sandboe had to bring in the chairman of NAVF's advisory committee on natural science, professor Per Maltby. Maltby, an astrophysicist, immediately saw the scientific value of our plans, but as many others, he saw problems with the budgets. He was himself trying to find money for Norwegian participation in European solar observatory projects. His advice was to try to obtain extra money for our project from the Ministry of education, through NAVF or directly to the University of Tromsø.

I was uncertain about how to approach the Ministry of education, and was very pleased when Anders Omholt offered his assistance. He got an appointment to meet with two of the top level administrators in the Ministry, and came with me to the first meeting with them. Enevald Skadsem, head of the Ministry's administration, had been strongly involved in preparing the basis for the Parliament's decision on establishing the University of Troms $\emptyset$. He was happy to see the University involved in international cooperation so soon, but found it difficult for the Ministry to allocate large sums of money for a particular project. Rather, NAVF and the University should apply for increased budgets to enable them to be more active in international cooperation, and the Ministry might be sympathetic to that! Still, if I remember correctly, the incoherent scatter project was indeed mentioned in the Ministry's budget proposition to the Parliament. Summing up, I felt that obtaining funds for the Norwegian participation did not seem too difficult.

\section{Convincing the "physics community"}

From the very beginning, it was our intension that the incoherent scatter radar we were planning should be used by all the ionospheric physics groups in Norway, not only by the Troms $\varnothing$ group. To my disappointment, the enthusiasm was not overwhelming. The reasons were, I think, twofold: the groups were successfully active in other types of ionospheric research, in particular rocket and satellite observations, and wanted to continue with that. Secondly, they feared that there would be less money for them, if the incoherent scatter project was realized. There were, certainly, individual exceptions to this, and later I felt the absolute support from Norwegian ionospheric physicists. Their interest to be active users seemed still to be lacking. I was very pleased that the director of NDRE, Finn Lied, encouraged me to carry on with the planning. Lied's field of research had been telecommunications and ionospheric physics, and although no longer active in research himself, he followed the field with interest. As member of the government, he had strongly supported the establishment of the University of Tromsø, and I thought his considerable political influence might be valuable if things got difficult. As the project developed, I cannot remember that I ever had to ask for his help.

Sandboe did a very good job of obtaining support within NAVF. I think it was very important that Per Maltby was positive, even if he was still worried of the budgetary consequences. I was also asked to present the plans to "Norsk fysikkråd" - an advisory board on physics research policy. As far as I remember now, the attitude there was quite positive. The cooperation with other countries was not progressing as fast as we should have liked. In fact, it seemed to us to be very uncertain when, if ever, we would get the necessary funding in all the cooperating countries. This may have contributed to make the opposition in Norway less active!

In the early 1970s, I think it was in 1972, NAVF and the University of Troms $\varnothing$ agreed to appoint members to a joint EISCAT Committee, to coordinate the work between the two and to represent Norwegian interests in the European cooperation.

\section{Recruiting a qualified staff}

The staff of the Auroral Observatory was supposed to form a basis for the physics department of the new university. Four or five of us had been working with radio wave investigations of the ionosphere, from VLF to VHF, the others had worked with photometric and spectroscopic auroral observations. Obviously, there was a need for more people, and in particular people experienced in radar experiments and plasma physics. We were fortunate to be able to offer 
positions, since the new university was given money for hiring staff at a time when budget cuts actually stopped even replacing vacancies at the other Norwegian universities. I was very pleased to receive applications from Jan Trulsen and Egil Leer. They had recently obtained their Ph.D. degrees from University of California at San Diego. Jan arrived in Troms $\varnothing$ in the fall of 1970, Egil nearly two years later. From Oslo came Noralv Bjørnå, also with a fresh doctor's degree. They all made very valuable scientific contributions in the following years, as well as serving on various EISCAT committees.

Asgeir Brekke had a temporary employment at the Auroral Observatory. In 1972 he obtained a fellowship to go to San Diego, were he worked in a group headed by Peter Banks. They were using the incoherent scatter radar near College, Alaska, and Asgeir received excellent training in operating the radar as well as planning experiments and using the data. Needless to say, this was very valuable for us when he returned to Troms $\varnothing$ two years later. Others, like Ove Havnes, who had obtained his doctor's degree in the Netherlands, were not so interested in the beginning, but later Ove found very interesting, and rather novel, applications of the radar. Kristian Dysthe was appointed professor of applied mathematics. He had a background in fluid dynamics and plasma physics and became a very active and important participant in EISCAT studies. I should also mention Ove Bratteng and Richard Armstrong, both of whom made valuable contribution in the preparatory work, but never became active users of the radar themselves.

From the very beginning, we had asked the advice of Tor Hagfors. I do not recall if I called him first, or if he, having heard of our plans, called me, but we met several times in Troms $\varnothing$ and in Oslo when he was in Europe for other reasons. The Auroral Observatory, and later on the University of Troms $\emptyset$, paid his extra travel expenses on these occasions. I introduced Tor to Adolf Sandboe at NAVF and I was happy to see that they got on very well together. Our partners in other countries were all very pleased that Tor Hagfors was actively taking part in the preparations. During this period, Tor was offered a position as professor at the Norwegian Technical University in Trondheim. If not the only reason, I think that the prospect of working with an incoherent scatter radar in Scandinavia made it easier for him to accept, and thus leave the US again.

Some time later, when the University of Troms $\emptyset$ was given the task of building the correlator for the EISCAT data processing, we were very lucky to be able to employ one of Tor's previous students in Trondheim, Hans Jørgen Alker, for that job. Hans Jørgen spent about two years in Troms $\emptyset$, and worked day and night. I am convinced that without his dedication, we would not have finished the design and construction of the correlator on time.

Finally, I will mention that together with Oksman and Hultqvist, I planned a summer school to introduce students and young scientists to the incoherent scatter radar technique.
This was made possible by a grant from The Nordic Council, and additional support from the University of Troms $\varnothing$, and the school was arranged in Troms $\varnothing$ in the summer of 1975, with participants from all the cooperating countries. Asgeir Brekke edited the proceedings from the summer school, published by Universitetsforlaget (Norwegian University Press) (Brekke, 1977).

\section{Progress in the international cooperation}

I was convinced that if we reached an agreement with three or more other countries, we should have the necessary funding for Norwegian participation. The funding seemed much more uncertain for our partners. The scientists, though, kept on with the technical discussions. Hultquist invited us to a meeting in Stockholm in September 1970, in order to obtain an agreement on the gross specifications of the radar system (Hultqvist, 2011). By that time, the French project for a shipborn radar had been cancelled, and the scientists behind the project were interested in working with us on an auroral zone radar. One purpose of the meeting was to see how the technical aspects of the two projects could be merged. Also colleagues in UK and Germany had expressed their interest, although without being able to commit themselves. The situation looked brighter!

The Stockholm meeting was followed by a series of meetings during the following months. The first of these took place in Nancay in October 1970. Richard Armstrong attended on behalf of the Troms $\varnothing$ group. The meeting resulted in major changes in the proposed facility. Discussions so far had been based on the assumption that the transmitter should be placed in Kiruna, with receivers in Kiruna, Sodankylä and Troms $\varnothing$. It was now agreed to have a monostatic VHF radar in addition to a UHF tristatic operation. Also, I think this was the first time it was suggested to consider placing the transmitters in Troms $\emptyset$. The next meeting was held in Troms $\varnothing$, in March 1971. I am not sure, but I think that we had a look at possible transmitter locations near Troms $\varnothing$. The status of plans for the different parts of the proposed system was reviewed, in order to be presented at the URSI European Regional Meeting to be held in Reading in the beginning of April. In Reading, Armstrong again attended from Troms $\varnothing$. and I am quite sure that Tor Hagfors was there. After the URSI meeting, we met again in Otaniemi, near Helsinki, in May 1971. A number of reference reports on parts of the equipment, interference problems, site locations, power requirements etc. had been, or were about to be, finished. We found that time was ripe for writing a complete proposal, with technical specifications, site requirements, cost estimates and cost sharing and possible organization. Our German partners offered to host a meeting for this purpose.

The small town of Titisee, in the Black Forest, not far from the border to Switzerland, was chosen for the meeting to take place in the middle of June. Richard Armstrong 
came with me to Titisee. Bengt Hultqvist was there from Sweden, du Castel and possibly Pierre Bauer from France, Harry Kohl and Gerhard Haerendel from Germany, Martti Tiuri and Aarne Ranta from Finland. UK scientists had not been allowed to take part in the process so far, as representing British institutions, but we had benefited from their advice as "consultants". Nick Taylor from RRE at Malvern was present at the Titisee meeting. Most important for the progress was that Tor Hagfors had found time to participate. The contents of each section were discussed between all of those present. du Castel, Hultqvist, Kohl, Tiuri and I were given as authors of the report, but large parts of the main sections were written by Hagfors. I left Titisee with the complete manuscript in my briefcase, and the report was published by the Auroral Observatory before the end of the month (June 1971). I think Liv Larsen at the observatory designed the front page. The printer (!) had chosen green for the color, and the report was later always referred to as "the green book" (du Castel et al., 1971).

\section{Organizing EISCAT}

The name EISCAT (originally proposed by Bengt Hultqvist) had come into use as we produced the green book. The report was presented at an URSI General Assembly in Warsaw in August. After that, the scientists continued the technical studies of parts of the system, but with the exception of France and Norway, funding seemed very uncertain. A meeting that was arranged at the European Council's office in Paris at the end of February 1972 did not bring us any closer to a solution on funding and organization.

In 1973 I had the pleasure of arranging an incoherent scatter conference in Troms $\varnothing$, on behalf of URSI Commission III. Scientifically I think this was a success, but as I remember, funding and organization was discussed only during coffee breaks and evenings. Adolf Sandboe got worried, because he felt that if we could not show some substantial progress soon, there were competing projects that would take interest (and money!) away from EISCAT. I think it was Tor Hagfors who suggested that we should appeal to Sir Granville Beynon, in his capacity as president of URSI. Sandboe grabbed the idea immediately and wrote to Beynon suggesting that he, Beynon, should call a meeting of representatives from all the countries involved. Beynon followed up, and the meeting took place at the end of October 1973. From Norway Adolf Sandboe and I participated, and also Tor Hagfors (this time his travel expenses was paid by NAVF, and not by the University of Troms $\varnothing$ ). I think it was at this meeting that Sandboe very boldly declared that "Norway will pay its share". I doubt that he was really authorized to make this statement, but he felt very strongly that somebody had to start!

It was decided to establish a Steering Committee, with F. Schneider, secretary general of the Max Planck Society, as chairman, and Tor Hagfors as secretary. From this meet- ing on, progress was steady, leading to the signing of the EISCAT Agreement in 1975. I think the activity in this period is well covered in EISCAT's own files. As for myself, I had been elected Rector of the University of Troms $\varnothing$ for a four-year period, and for the most part, others took over for me in representing Norwegian scientists in the EISCAT cooperation.

\section{Constructing and building the radar system}

At an earlier stage (I do not remember when) we had decided that the different countries should be responsible for the design of different, well defined parts of the radar system, and to the extent that it was possible also carry the cost of said parts. It fell upon Norway (with some assistance from the Finnish group in Oulu) to develop the data processing equipment. One part of this was a specially designed, very fast preprocessor, later called just the "correlator". Results of the preprocessing should then be fed into a data handling system, based on minicomputers, commercially available. These computers should then be used in the further processing of data into the interesting physical parameters, and also in the control of the transmitter and receiver parameters to be used for the different experiments as well as the communications between the transmitter/receiver sites. A user-friendly language (high level) should be developed for these purposes.

I had expected lengthy discussions on the choice of minicomputers. I was approached by representatives of the quite successful Norwegian company Norsk Data AS: that was only to be expected, and showed that they were aware of the possibility to get their machines into an interesting market. Norsk Data had recently obtained a rather large contract with CERN. I was a little surprised to hear from people in the Ministry of industry and within NAVF and NTNF that we "ought to buy Norwegian". My answer was that this was an international cooperation, and we had to find the best suited machines. Our French colleagues saved us a time-consuming evaluation. From French physicists working in and/or with CERN, they had received very strong recommendations for the Norsk Data computers. At the University of Troms $\varnothing$ we had been using ND computers for some time, with good results so far, so we were very pleased when agreement was reached to use these for the EISCAT data processing and control system.

The preprocessor, or correlator, had to be specially designed for the purpose. We had inquiries from ND and one or two other commercial companies, but realizing that there would not be a wider market for this machine, they quickly lost interest. Some of the research institutes in Norway were interested in doing the job on a contract basis. At least two of them definitely had the capability. I was not happy with that possibility, mainly because we would have to pay out cash, whereas if we could do the job in our own lab, we could 
use manpower as "in kind payment" - a principle accepted by EISCAT. As mentioned above, we were fortunate to employ Hans Jørgen Alker to do the job. Alker's Ph.D. theses at the University of Trondheim was a design study for a digital correlator for EISCAT, so he did not start from scratch in Troms $\varnothing$. Still, the construction and building of a prototype was challenging and time consuming. Unfortunately for us, Alker decided to return to Trondheim after two years in Troms $\varnothing$. The prototype for the correlator was then nearly finished. Arrangements were made so that a small group from the electronics lab at the Auroral Observatory continued the work, with Alker as project supervisor. The group in Troms $\varnothing$ also build the units to be used in Kiruna and Sodankylä. The prototype is described by Alker in an EISCAT technical note (Alker, 1979). Terrance Ho made valuable contributions to the programming of the correlator (Ho and Alker, 1981).

Acquiring the land for the transmitter/receiver site in Troms $\emptyset$ should also be mentioned here, since the EISCAT files are not likely to contain any information on that. EISCAT approved of an area bordering a field station that the $\mathrm{Ob}$ servatory had at Ramfjordmoen. It turned out that there were more difficulties with renting the land than I had anticipated. This had to do with the municipality's and the county's long term plans for land use. I shall not go into details on this. but I will say that I was very grateful for the assistance given by the University's "campus development department", in particular Karstein Sandvik, who headed that department then. As I remember, the result was that the University rented the land and sublet it to EISCAT. I think that has been the arrangement ever since, and the rent paid by the University is probably part of the Norwegian contribution to the operating costs of EISCAT.

\section{0}

\section{Looking back}

Following my four year period as rector of the university, I resumed my work in teaching and research in the physics group. In the following years I served on EISCAT's Council and on SAC (the Science Advisory Committee). I also enjoyed taking part in experiments with the very powerful HF transmitter that the Max Planck institute in Lindau had installed at Ramfjordmoen (the heating experiments). In 1985 I accepted the position as director of the University's Foundation for applied research, and my formal connections with EISCAT came to an end. It has been a pleasure to follow the activities of the organization, and I was very proud to be invited to the inauguration of the first EISCAT Svalbard radar. During the years 2002 to 2005 I was again involved in EISCAT matters, as a consultant to the University of Troms $\varnothing$ and the Norwegian Research Council.

I have been privileged to take part in starting a number of activities and organizations. Most important is probably the University of Troms $\emptyset$, but personally I am most proud of the role I played in getting EISCAT started and operating.
Acknowledgements. I thank the referees for their corrections and valuable comments.

Edited by: A. Brekke

Reviewed by: B. Hultqvist and two other anonymous referees

\section{References}

Alker, H. J.: A Prorammable Digital Correlator Module for the EISCAT Radar System, EISCAT Technical Note 79/11, 1979.

Bowles, K. L.: Observations of Vertical-Incidence Scatter from the Ionosphere at $41 \mathrm{Mc} / \mathrm{sec}$, Phys. Rev. Lett., 1, 454-455, 1958.

Brekke, A. (Ed.): Radar Probing of the Auroral Plasma (book), Universitetsforlaget, Oslo, 1977.

Du Castel, F., Holt, O., Hultqvist, B., Kohl, H., and Tiuri, M.: A European Incoherent Scatter Facility in the Auroral Zone (EISCAT), published by the Auroral Observatory, Troms $\varnothing$, June 1971.

Gordon, W. E.: Incoherent scattering of radio waves by free electrons, with applications to space exploration by radar, Proc. I.R.E., 46, 1824-1829, 1958.

Hagfors, T.: Incoherent Scattering of Radio Waves as a Method of Studying the Ionosphere, in: Electron Density Profiles in the Ionosphere and Exosphere, edited by: Maehlum, B., Pergamon Press, Oxford, 337-347, 1962.

Ho, T. and Alker, H. J.: Scientific programming of the EISCAT Digital Correlator (revised), EISCAT Technical Note 81/24, 1981.

Hultqvist, B.: History of EISCAT - Part 1: On the early history of EISCAT with special reference to the Swedish part of it, Hist. Geo Space. Sci., 2, 115-121, doi:10.5194/hgss-2-1152011, 2011.

Oksman, J.: History of EISCAT - Part 2: The early history of EISCAT in Finland, Hist. Geo Space. Sci., 2, 123-128, doi:10.5194/hgss-2-123-2011, 2011. 